\title{
1. Introduction: the reform and opening-up of a large, developing country
}

Rapid growth accompanied by unbalanced development is the best way to describe the path taken by a large, developing country over the past 30 years - China. Even today, China is constantly adjusting its system to accommodate ever-changing challenges.

In 1978, China had just completed the Great Proletarian Cultural Revolution and the country was in the very earliest stages of its reconstruction. The green shoots of change began to appear quietly in the spring, although at the time most people did not notice. In December, the Communist Party of China (CPC) held the Third Plenary Session of the 11th Central Committee, which announced the prolog of the reform and opening-up policy.

Eleven years later, after the serious political disturbances of 1989, the whole country regarded the concept of market-oriented reform with great suspicion and mistrust. In 1992, Deng Xiaoping, speaking in southern China, remarked, 'For a big, developing country like China, rapid economic development cannot always be accompanied by smoothness and stability ... Development is the foremost and essential principle' (Deng Xiaoping, Vol. III, 1993, p. 377).

Beijing's hosting of the 29th Olympic Games in the summer of 2008 was a coming of age, showing that China had grown from a developing country characterized by poverty and backwardness to an economic giant. This was not only the year after the 17th Party Congress but also the 30th anniversary of the launching of the reform and opening-up policy. Thirty years earlier, 'Olympic' was a term that was unfamiliar to the Chinese people. By 2008, however, the map of the world's economy had changed and China had undergone a great deal of development.

Not only has the world's economic map changed since China began its reform and opening-up, but also, as described by US political scientists Townsend and Womack (1986) in their comments on Chinese-style socialism, there is a strong belief that China has taken a different route toward development from other countries. For this reason, China should 
be considered a unique case. After more than 30 years of reform and opening-up, China's achievements and response to challenges not only inspire awe, but also raise many questions, including what are the differences between China's path toward development and those taken by other countries, whether China can realize sustainable economic development, and what other developing countries can learn from China's model.

Like China, the former Soviet Union and countries in Eastern Europe have had planned economies. These countries also began radical transitions into market economies in the late 1980s, though these may have differed from China's 'exploring through practice' reform strategy. At one time, economists thought that China had achieved success through a gradual and smooth progression of incremental reforms and that this strategy had prevented the economic recessions that can be caused by hasty actions. Today, from a viewpoint of standard economic theory, China's transition could be considered a basic establishment of a market economy system characterized by the free determination of prices and free mobility of factors. The private sector accounts for an overwhelming amount of China's whole economy. However, China's development path is more complicated than a simple transition from a planned to a market economy. We must reevaluate the meaning of 'development' and then analyze China's 30-year experience of reform and opening-up from a much wider perspective, taking into account its status as a large, developing country.

In this book, we analyze China's economic process on the basis of the system structures of a large country. We here interpret 'development' as changes in the interactions between the economy, politics and society. It is our view that two key factors that have affected China's economic path are that it is large and that it is a developing rather than a developed country. Because it is large in terms of population, territory and economic scale, it has a broad domestic market that leans toward scale effects and a significant supply of public goods (including the development of national defense, technology and strategic industries). In order to realize the advantages of its size, China has favored political centralization because it promotes national unity, political stability and policy implementation. In order to overcome the disadvantages of heavy centralization of power, the central government supports economic decentralization, which offers local governments more autonomy to make local economic policies and to share the increased tax revenues produced by the development of the local economy. Thus, China's mode of governance is in accordance with its status as a large country. Within this kind of system structure, marketoriented reform and opening-up can foster stunning economic growth. However, it can also cause two types of imbalances: internally, there is 
uneven development not only between the urban and rural areas but also across regions, and imbalances in the distribution of public services within the country; externally, trade surpluses and external imbalances may be created.

As a developing country, China has another structural feature: strong social relationships in almost all transactional processes. Some scholars call China a 'relationship-based society'. In the early stages of economic development, social connections can lower transaction costs. However, once the social network becomes embedded in the new market system, it can aggravate social inequality and provide a structural background for internal and external imbalances during periods of rapid growth. These inequities may be rendered more intense by the combination of political power and social relationships. Under decentralized economic systems, the localization of social relations can strengthen the localization of the economy, which does not favor market competition or scale economy.

For sustainable economic development, the challenge of dual imbalances can serve as an impetus to promote further adjustment of system structures and to improve the market economy system. China's development involves interactions among the economy, politics, and society as well as the construction of a socialist market economy with Chinese characteristics. China has selected the market economy system as its fundamental method of resource allocation. However, this system must be tailored to China's long and rich history and to all the particular issues of large, developing countries.

\subsection{CHINA'S 30-YEAR PATH TO REFORM AND OPENING-UP}

The report of the 17th CPC National Congress summarized China's achievements over the past 30 years. It described how large-scale reform and opening-up were why China had 'successfully realized a great historical transition from a highly centralized planned economy system to a dynamic socialist market economy; from an isolated, to a semi-isolated system to a fully opened-up one'. The policy of reform and opening-up has transformed the market economy system into a basic form of resource allocation, allowing the economy to develop vigorously. However, the existing political and social structures have also had an undeniable effect on this newborn market economy system. This has caused many distortions in the market economy system and some imbalances in development.

According to traditional views, it is indisputable that the transition from a planned to a market economy system was a rough one. China still has 
regulated exchange and interest rates, a relatively inflexible cross-regional flow of the labor force, and a segmented interregional commodity market, but it is likely that these issues will all be solved in the foreseeable future. In view of various drawbacks found in the current market economy system and the challenges posed by economic development, we may conclude that there is no direct or necessary connection between a traditional planned economy and the various drawbacks and challenges currently faced by China. In other words, in order to understand the current problems, it is necessary for us to consider economic transition as a much wider type of development, one that includes but also goes beyond the traditional view of a mere transition from a planned to a market economy. In this section we first outline China's 30 years of transition from a planned to a market economy.

According to traditional economic theories, China has completed two major tasks during the past 30 years of development, the implementation of reforms at home and the opening-up to the outside world.

\section{Reforms at Home}

History has proved that planned economies can be inefficient. There are two reasons for this inefficiency. First, in a planned economy system, the central government decides on prices and allocates resources, and information asymmetry can have huge effects (Hayek, 1945). Second, planned economy systems are often troubled by incentive problems. Because of the information asymmetry that is common in certain types of organizations, inefficiencies such as shirking and free riding become universal unless proper price mechanisms and incentive mechanisms are put in place (Stiglitz, 1994). Leaders like Deng Xiaoping drew similar conclusions after years of practical experience. After several years of experiments and arguments, the Central Committee's Decision on Economic System Reform was unanimously adopted in the Third Plenary Session of the 12th CPC Central Committee. Among other points, the committee agreed that 'a reasonable price mechanism should be established, thus the price could sensitively reflect changes in labor productivity and the relationship between supply and demand' and that 'only if we fully develop the commodity economy, can the economy be dynamic and enterprises be more efficient, more flexible, and more sensitive and adaptable to complicated social needs'. China's market-oriented reform and opening-up was designed to fundamentally correct the disadvantages in the planned economy system.

Marketization has changed the allocation of economic resources. China adopted a dual-track system that incorporated both market-determined 
and planned prices as a transitional way of realizing price liberalization in the commodity market. It did not truly establish a factor market until the second half of the 1990s. Specifically, 1994 was the watershed year. In order to prepare for the market mechanism, reform prior to 1994 first fostered a non-state sector. This system operated according to market mechanisms outside the state sectors instead of following fundamental reform measures toward traditional state sectors. For this reason, some economists referred to China's reform as incremental reform, outside system reform, or a dual-track system (for example, Fan, 1994; Lin et al., 1994; Naughton, 1994). With regard to the reform sequence, many economists considered China to have adopted a strategy of avoiding the important and dwelling on the trivial, or easy first and difficult later.

For the commodity market, from the 1980s to the early 1990s, China adopted a dual-track pricing system. This allowed private enterprises to sell surplus commodities at prices exceeding the planned price so long as they first completed their planned production. In the unplanned market, supply and demand were still marginally allocated by price mechanisms (Byrd, 1989; Yuan, 1994; Zhang, 1997). Dual-track reform not only rendered the planned economy more efficient but also offered widespread benefits to the people without incurring any losses to anyone (Lau et al., 1997, 2000). Although it accelerated the growth of the commodity market, the dual-track system also fostered corruption as the track transitioned from planned to unplanned. After the 1990s, production plans were gradually cancelled, and the dual-track commodity market system was incrementally transformed into a single-track system. This transition continued until China finally realized free pricing in the commodity market. Land, capital and labor are the three main production factors in this type of market. In the 1990s, marketization reforms were also undertaken in the production factor market. A land-leasing market was developed, a stock market was set up and a labor contract system was also enacted. Although these three markets became significantly more sophisticated, it is generally thought that they lag far behind the commodity market and that free flow and market pricing have not yet been fully realized in these areas.

Second, marketization has changed the incentive structure of economic agents. In a sense, the achievements of China's economic reform were a result of correct incentives rather than correct prices (Yongqin Wang et al., 2006, 2007). China's reform involved an effective incentive structure on three levels. At the state administration level, the combination of economic decentralization and political centralization inspired local governments to increase their tax base and local fiscal revenue by developing the local economy. At the same time, governments at all levels assess the governments one level below them on the basis of GDP growth rate and 
achievements in investment promotion. Both these issues affect the government officials' chances for promotion. This kind of system encourages local government officials to pursue economic growth.

With respect to the way business enterprises are organized, post-reform China has gradually developed an effective enterprise administration structure and an effective incentive system. Since 1985, China has implemented several reforms for state-owned enterprises (SOEs). These include a contract managerial responsibility system, a lease system, and a responsibility system for asset management. By the end of 1987, 78 percent of the enterprises in the country had implemented contract responsibility systems. Of these, 80 percent were large or medium-sized enterprises. Empirical research has shown that the bonus and contract-labor systems were the main reasons for 67 percent of the increase in per capita output in SOEs and 4.68 percent of the increase in total factor productivity (TFP) seen per year from 1980 to 1989 . Meanwhile, the management culture changed, rendering managers with poor performance more likely to be replaced (Groves et al., 1994, 1995).

A great number of enterprises suffered losses due to a bureaucratic phenomenon: in the case of losses in practical operation and contract responsibility systems, SOEs deduct a percentage from earnings but they are not required to pay compensation. People recognized that SOEs needed a more thorough reform for enterprise property rights and corporate governance. In the late twentieth century, China underwent a nationwide wave of privatization, mostly of small and medium-sized SOEs. This resulted in the very first reduction in the number of SOEs, from 104,700 in 1993 to 102,200 in 1994. The number of state-owned industrial enterprises was 113,800 in $1996,98,600$ in 1997 , and 50,700 in 1999. Nearly all the township enterprises became privatized in a very short period.

In the mid-1990s, economists recommended that entrepreneurs attain the residual claim of enterprise management (Zhang, 1995a, 1995b). Enterprises also needed a competitive product market, a capital market, and a manager market to provide enough information for corporate governance (Lin et al., 1997). Later, reform to invigorate large enterprises and relax control over small ones was implemented, and denationalization of most small and medium-sized SOEs and the merging and restructuring of large and medium-sized SOEs caused the number and range of SOEs to drop significantly. The number of state-owned and state-held industrial enterprises decreased from 64,737 in 1998 to 41,125 in 2002. The number of enterprises run by the central government decreased to 2,790. The rapid privatization of SOEs was related to the incentives obtained by local governments under the decentralization system. The privatization of poorly run SOEs can ease the government's financial burden and increase the 
tax base by improving enterprise performance. The transformation of enterprises has improved enterprise performance (Bai et al., 2006; Hu et al., 2006).

At the micro level, post-reform China has established a distribution system based on performance. The theoretical basis of the traditional, planned economy distribution system was that labor creates value. However, labor input was mainly measured by time spent, which did not reward labor quality or human capital. Workers had little incentive to invest in their education or return to school. When the system was changed so that rewards would be distributed according to individual performance, workers had an incentive to work harder. The implementation of the Household Responsibility System (Jiating Lianchan Chengbao Zeren $Z$ hi) enabled peasants to sell their output over the planned quota at market prices. Studies have found that, from 1978 to 1984, agricultural output increased more than 61 percent, more than three-quarters of which came from the improved incentive mechanism and one-quarter from the improved price system (McMillan et al., 1989). In cities, numerous selfemployed households became ten-thousand-yuan households during the 1980s. These were the first batch of people to become rich with the help of market mechanisms. In enterprises, salary reform, the introduction of a bonus system and hourly and piecework wages based on performance produced more incentives for employees and managers to increase work quality. Production efficiency improved dramatically (Groves et al., 1994, 1995). The number of employees returning to school for more education increased significantly after marketization reform was enacted ( $\mathrm{Li}$ and Ding, 2003; Zhang et al., 2005).

\section{Opening Up to the Outside World}

Before 1978, China's main economic goal was to catch up to and surpass other countries. This was achieved by means of speeding up capital accumulation and developing heavy and chemical industries, which could not make full use of China's economic potential. Meanwhile, due to the distorted production system and an exchange rate that overvalued the Chinese currency the renminbi (RMB), products made in China were uncompetitive, forcing the country to maintain its planned economy and remain isolated from the outside world.

China's opening-up policy involved participation in economic globalization, which allowed it to reestablish its comparative advantage. The strategy of opening up to the outside world can be considered indicative of a change in attitude from catching up to establishing a comparative advantage; from import substitution to export orientation. Historically 
speaking, both 1994 and 2001 were key turning points in the opening-up process.

The period from 1978 to 1994 was the first stage of China's reinvolvement in the international division of labor. During this period, the overvalued RMB exchange rate had not yet been changed substantially; but the Chinese labor market had a serious advantage with respect to costs and quality, quickly outstripping other countries in the international labor market. This caused China's international trade and foreign capital investment to grow rapidly. Before 1979, international trade was under the control of a centrally planned economic system; the central government controlled over 90 percent of trade volume by monopolizing the import and export of more than 3,000 types of goods. By 1991, nearly all imports were decontrolled, and only 15 percent were still controlled by specific trade companies. All exports were decontrolled. By 1994, almost all planned systems for imports and exports had been abolished. Only a very limited number of important goods were still controlled by specific companies.

China has become one of the biggest destination countries for foreign direct investment (FDI) in the world. It is also one of the biggest production bases in the global manufacturing system. In 1979, in order to attract FDI, special economic zones were founded in Shenzhen, Zhuhai, Shantou, and Xiamen. However, little large-scale FDI appeared before 1984, when, in order to attract more foreign capital, another 24 economic open zones, including 14 coastal cities, were made available to foreign investors. From then on, an increasing number of economic open zones were established for the purpose of encouraging foreign investment and technology transfer (Chapter 4). After Deng Xiaoping made his famous remarks during his inspection tour of southern China in 1992, a second wave of FDI appeared in China.

In this way, 1994 was a watershed year for China's reform and opening-up with respect to exchange rate reform. With the execution of reform, including trade system reform, the nominal rate of exchange, which had long overvalued Chinese currency, faced the pressure of extreme devaluation. During this period, in order to encourage exports and increase reserves, China began to adopt the dual-rate system, which involved an internal settlement exchange rate of 2.8 yuan per US dollar for exchange, settlement, and sales while keeping the official RMB exchange rate at 1.5487 yuan per US dollar. The reform of the financial and exchange rate systems required that price controls be eliminated and that the real value of the RMB be determined by the actual exchange rate, which would involve devaluation. Official exchange rates dropped gradually during this period. In 1994, the dual-rate system was formally 
withdrawn. Unification of exchange rates and the drastic devaluation of the RMB was the new starting point for China's export-oriented strategy.

The year of 2001 was another key point in time for China's opening-up to the outside world. In 2001, China joined the World Trade Organization (WTO), which announced China's integration into the global trade system as a market economy. China was no longer a simple participant in international business. Instead, it began to influence the international cooperation and trade systems as major trading power.

\section{Achievements of China's Reform and Opening-up}

The report of the 17th CPC National Congress presented a highly generalized account of the achievements in China's 30 years of reform and opening-up. According to the report,

[T] he economy of our country boomed from the edge of collapse to the fourth place in the world, with the volume of imports and exports ranking third in the world; the standard of living had improved from starving to well-off, and the number of poor people in the countryside had decreased from over 250 million to around 20 million.

China's achievements could generally be represented by changes in numbers.

First, the economy grew rapidly, with GDP (calculated at comparable prices) growing by a factor of almost 16.5 from 1978 to 2008; the actual growth rate was 9.8 percent annually on average. The reform and opening-up could be divided into two stages according to comments made by Deng Xiaoping during his inspection tour of southern China in 1992. The average growth rate was 9.4 percent from 1978 to 1992 and it exceeded 10 percent from 1992 to 2008. Along with rapid development, China's international economic status also rose quickly. As the economy developed, China's human development index increased sharply from only 0.527 in 1975 to 0.768 in 2004. Even so, it still ranked 81st in the world. ${ }^{1}$

Second, China integrated itself into the wave of economic globalization. The total volume of imports and exports was only US\$20.64 billion in 1978 but it increased eightfold to US\$165.53 billion in 1992. The increase was even more substantial after 1992, reaching US\$2,207.53 billion, which is over 100 times the 1978 value. Since the implementation of reform and opening-up, China's ratio of dependence on foreign trade (the proportion accounted for by total value of imports and exports in the GDP) increased steadily from 10.8 percent in 1979 to 35.36 percent in 1992 and even to 65.17 percent in 2006. It then declined to 44.24 percent in 2009 due to the recent 
economic crisis. China has already become a genuinely open economy, and the trade-to-GDP ratio in other economies such as the United States, Japan, and India was about 20 percent. $^{2}$ At the same time, FDI in China became more and more intense. It amounted to only US $\$ 1.769$ billion in the period from 1979 to 1982 but, in 2005, it reached US\$60.325 billion, and the ratio of FDI to GDP reached 2.7 percent. In 2009, FDI amounted to US\$90.033 billion and the ratio of FDI to GDP reached 1.8 percent in 2009 (exchange rate calculated by average annual price). ${ }^{3}$ China's status in the international division of labor has consistently grown stronger; the ratio of finished products to total exports was $49.7,80,94.5$, and 94.75 percent in 1980,1992 , 2006, and 2009, respectively. ${ }^{4}$ Although there is a great gap between China and developed countries in terms of manufacturing technology, it is indisputable that commodities made in China are sold almost worldwide.

Third, China has undergone an accelerated process of urbanization and industrialization since reform and opening-up began. Since 1978, the process of urbanization had been greatly promoted and the proportion of urban population increased from 17.92 percent in 1978 to 27.63 percent in 1992. Since 1992, urbanization has proceeded even faster: the proportion of urban population increased to 43.9 percent in 2006 and 46.59 percent in 2009. However, China's urbanization level remains relatively low compared to other countries; rural residents account for about 50 percent of the total population. In contrast, the relative amount of primary industry in GDP has dropped consistently from 28.2 percent in 1978 to 11.8 percent in 2006 and 10.3 percent in 2009. The relative amount of secondary industry in GDP continued to increase from its relatively high level of 47.9 percent in 1978 to 48.7 percent in 2006 and 46.3 percent in 2009. With the increased importance of tertiary industry, the proportion of tertiary industry in GDP increased from 23.9 percent in 1978 to 34.8 percent in 1992, then to 39.5 percent in 2006 and 43.4 percent in $2009 .{ }^{5}$

\section{Termination of Transition?}

Thirty years of reform and opening-up has led one-fifth of the world's population down the path of modernization, which almost certainly has worldwide significance.

Over the past 30 years, China has established what can be called a Chinese-style socialist market economy. The period from 1992 to 1994 was an important turning point, in which the reform in marketization grew beyond the preliminary stage. China experienced a serious political incident in 1989, which caused a conservative backlash with respect to marketization reform. During his visit to southern China in the winter of 1992, Deng Xiaoping issued a series of important statements regarding the 
promotion of continuous marketization reform. These inspired people to support marketization reform wholeheartedly.

During the period from November 11-14, 1993, the 14th CPC Central Committee approved the Decision of the CPC Central Committee on Several Issues Concerning the Establishment of a Socialist Market Economic System, which set a goal of establishing a preliminary socialist market economic system by the end of the twentieth century. In 1994, marketization reform was greatly advanced in four ways:

1. reform of the financial and taxation systems: to change the original system of central and local governments taking full responsibility for their finances into the system of tax sharing between central and local governments (including provincial and county governments);

2. reform of the financial banking system: to establish a financial organization system in which the SOEs are the mainstay, along with coexistence of various financial institutions and separation between non-commercial (policy) and commercial finance;

3. reform of the foreign exchange management system: to unify exchange rates and manage convertibility of the RMB under the current account; and

4. reform of state-owned enterprises: to promote further transformation of the enterprises' management mechanisms in order to establish a modern enterprise system able to adapt to the requirements of the market economy characterized by clearly established ownership, well-defined power and responsibility, separation of enterprise from administration, and scientific management.

China's marketization reform made great strides forward in 1994. If the problems addressed by the reforms of the 1980s were mainly related to the development of industrialization and urbanization, then the problem addressed by the reforms of 1994 was system transformation. Substantial development was achieved in terms of establishing the factor market and opening up to the outside. After 30 years of reform and opening-up, China may have reached its goal of transitioning from a planned to a market economy, but several questions remain.

\subsection{NEW HISTORICAL STARTING POINTS OF REFORM AND OPENING-UP}

At the 17th CPC National Congress, it was asserted that China is encountering a 'new historical starting point' of reform and opening-up, 
moving toward the goal of a generally prosperous society. The history of transition from planned to market economy is not sufficient to illustrate the opportunities and challenges that China will face with respect to economic, social, and political development in the coming years. China needs to adjust its development goal away from the pursuit of growth and one-sided efficiency toward the pursuit of fairness and general well-being. The government is now moving towards democratic politics that promote a harmonious society. China is attempting to solve the problems left over from the last 30 years of market-oriented reform and opening-up. From our point of view, the contradictions and problems that the country faces today are related to the centralized political structure, decentralized economic structure and relationship-based social structure. These two structural characteristics have not changed substantially, despite the reforms of the past decades. China must solve these problems by adjusting its economic, political and social structures.

\section{Seven Current Challenges}

For China to continue developing as a world economy while still pursuing the goals of fairness and prosperity at all levels of society, it must overcome seven challenges.

\section{The relationship between short-term growth and sustainable development}

The rapid growth of China's economy, which has lasted more than 30 years, may or may not be sustainable. Under the system of economic decentralization, the assessment and promotion of local government officials was fundamentally dependent on economic growth and the achievements of investment. However, the term of office of local officials usually lasts only a few years, so local governments often ignore many goals that foster continuous economic growth and sustainable social development, including education, health services, and environmental protection, and instead prefer high levels of short-term growth. Under the system of fiscal decentralization, these services require financial support from local government. However, increasing financial support can involve directing funds away from government investments that benefit short-term economic growth, such as investments in infrastructure. As a result, industries that would promote long-term sustainable development but require large amounts of financial support tend to be ignored (Yongqin Wang et al., 2006, 2007; Fu and Zhang, 2007).

\section{The relationship between national and local interests}

In an economically decentralized system, it is difficult to avoid conflict between the goals of central and local governments. Central governments 
tend to represent a nation's interests, while local governments tend to represent local interests. The differences between the goals of central and local governments can manifest in several ways. For example, central governments tend to prefer sustainable development, and local governments tend to focus on short-term goals. The central government pays more attention to peasants' interests, but local governments lack incentives to pay attention to rural development because so much of their incentive is based on growth. The central government tends to prefer to improve the unification of the domestic market, whereas local governments pursue short-term local interests through regional protectionism and market segmentation. In China's case, provincial governments have shown increasing economic power and negotiating skills. This can undermine central policies. One of the advantages of a system of fixed tenure and a rotation of management across regions is that it can reduce the difference between local and central interests. However, this system also has one major problem: local officials then lack incentives to pursue the long-term goals of sustainable development.

\section{The relationship between government intervention and social development}

Under the system of economic decentralization, in order to pursue national interests, we need a powerful central government to ensure that central policies are carried out effectively. China has therefore adopted a system of political centralization in order to cooperate with the system of economic decentralization. However, in systems involving heavy political centralization, the strong bureaucratic organizations that give governments much of their practical power tend to manifest at all higher levels of government, but are unlikely to be seen at lower levels. Overly powerful governments and insufficient restraint of personal power can render economic and social development too dependent on specific qualities and abilities of individual government officials. Under the strong government model, the entire society can fail to reach advanced and effective social organization or develop self-organized systems for the allocation of resources and mediation of conflicts. However, many governments are unwilling to permit social organizations to take over responsibility from them, for the sake of their own interests.

\section{The relationship between urban and rural residents: social integration}

China's urbanization level is still low. The rapid promotion of urbanization will continue to be an important phenomenon in the development of the economy for several decades to come. However, under the current administration structure, in which the city governs the countryside, urban governments make urban-biased economic policies that protect urban 
residents' interests over those of rural residents. This is especially true with respect to public services such as employment, social security, education, and medical care (Lu and Chen, 2004, 2006a). Long-term implementation of policies in support of the urban-rural divide has caused large gaps in income and public services. Increases in both the amount of urban space and the number of migrants lacking local household registration (hukou) in cities to which they have moved have translated the urban-rural divide into social segmentation between people with and without local hukou identity in urban areas. In cities, the gaps in income and returns on education between residents and migrants have widened (Meng and Bai, 2007; Zhang and Meng, 2007). This may further intensify social conflicts within cities and therefore affect the sustainable development of cities. Improving urban-rural integration and social integration within cities is a major issue.

\section{The relationship between developed and backward areas: market integration}

Economic development can differ widely by region. Natural conditions and geographical positions are two important reasons for this. Ports in coastal areas are closer to the international market, which makes it easier for them to attract foreign investment and offers them more opportunities to participate in international trade and realize economic development (Wan et al., 2007). The priorities of economic policy can also account for the wide gap among regions following reform. Until the late twentieth century, the fiscal transfer of central governmental funds was directed more to economically developed areas than to less-developed ones, which intensified the gap among different regions. This situation did not change until the twenty-first century. The widening gap among regions and the ability of local governments to make local policies allowed the proliferation of various market segmentation policies that protected local enterprises and increased employment and taxation ( $\mathrm{Lu}$ and Chen, 2006b). Market segmentation and regional protectionism are not only harmful to the unity of the market but also make it harder for China to capitalize on the scale of its large population and vast land resources to realize economic growth. Devising a reasonable system that can promote market integration and coordinate the development of a regional economy, therefore presents a major challenge.

\section{The relationship between economic growth and social harmony: interest sharing}

The income gap and unequal distribution of public services between urban and rural areas and across regions are all increasing. The combination of 
public power and social relationships in bureaucratized administrative systems also promotes inequality of political and social resources, which affects income and public services. Income inequality is harmful not only to the sustainable growth of the economy but also to many other aspects, such as the health status of the population, environmental protection, rural and urban poverty, public trust, and social stability (Lu et al., 2005; Wan et al., 2006). Meanwhile, the unequal distribution of public services, such as education and healthcare can lead to inequality with respect to long-term income, which may spread the inequality of human capital and income from generation to generation, decrease social mobility among various groups of people, and produce a series of related negative effects on the harmonious development of society and sustainable economic growth. Therefore, preventing the widening of the income gap and the maintenance of social mobility among all levels of society in order to render the achievements of economic growth more beneficial to more people may be favorable to China's future.

\section{The relationship between internal development and external imbalance}

China's speedy economic growth has significant relevance to all humankind. However, its increased strength has also provoked some anxiety in other countries. China's urban-biased policies, intensive competition in the urban labor market, the low cost of labor, the undervalued RMB, and the government's unilateral pursuit of economic growth, which many consider to be at the expense of laborers' rights and interests, have been problematic for some time. The cost of export products has fallen steadily since the mid-1990s, and labor productivity has increased, strengthening its exports, which began to increase even faster after the country's entry into the WTO. This led to trade imbalances between China and other countries, especially the United States. Although these are largely due to the low savings rate and brisk demand for imports from the United States, the low cost of China's export products is also a significant element. China's investments around the world and its need for global resources have increased. The idea of a harmonious world embodies China's responsibility to the world and its goodwill.

China faces numerous difficulties in its development, each with their own causes. ${ }^{6}$ However, all of these problems have a common background in the decentralized political-economic structure and relationship-based social structure. Unequal distribution of political, social, and economic resources can appear among different regions and across different groups of people. This can cause inequality in income and public services, creating internal imbalances. This situation is unfavorable to sustainable development, but it is often ignored by local governments in their unilateral 
pursuit of economic growth. Because laborers are socially disadvantaged (especially laborers who migrate to cities from the countryside) and because competition in the labor market is intense, the cost of labor has remained low relative to labor productivity, and the volume of both imports and exports has grown quickly. From a macroeconomic perspective, the growth of China's domestic economic consumption has been slower than the growth of its GDP. Thus, China's rapid economic growth depends heavily on investments and exports, which can cause external imbalances.

The problem of internal and external dual imbalances has been part of China's economic development throughout the past 30 years of reform and opening-up. Changes need to be made in order to realize sustainable development, and China must adjust its political and social structures, which have remained unchanged for a long time.

The word 'development' not only encompasses economic development or the processes of industrialization and urbanization but also the allround development of an economy, political system, and society. More and more economists have recognized that the process of industrialization and urbanization is only one aspect of development. Development is an interactive process incorporating, economy, politics, and society; it cannot be considered independent of political and social change.

\section{On the New Historical Starting Point of Reform and Opening-up}

The report of the 17th CPC National Congress announced that the reform and opening-up would create a new historical starting point, allowing China to proceed on a sustainable path through adjustments in the relationships among the government, market, and society.

\section{Changing relationships among government, market, and society}

The basic features of the market economy system are, superficially, the marketization of the pricing mechanism and the liberalization of the flow of commodities and factors. However, the current market economy system has certain evident political and social characteristics. Under the system of economic decentralization, the developing model of a strong government has not yet deviated from its roots. Various direct and indirect governmental interventions still exist through the resource-allocation process. Non-market mechanisms are still heavily mixed with market mechanisms. Research shows that the registration of residence, political status, family background, and social network still has important implications with respect to personal income, education, and political participation.

Under the current system, inequalities exist among different people in 
terms of political and social resources, which in turn intensify the inequalities in income and public services and challenge sustainable economic growth. Therefore, for the purpose of economic growth, China should adjust its political and social structures in two ways.

On one side, the political structure should transition from an administration-oriented government to a service-oriented one. At the early stages of economic development, the support of a strong government is vital to a thriving economy, particularly to the private sector, which was relatively weak in China and could never have created the infrastructure or large-scale industry built by the government. Other economies in East Asia have also been dependent on strong governments early on during economic booms. However, the current phase of economic development is totally different from that of the late 1970s. First, China's private sector has become increasingly stronger, and the importance of government in the promotion of the economy is not as great as it was. Second, the complexity of market information has increased, which increases the government's information disadvantage. Third, the development of infrastructure has reached a sufficiently high level, especially in coastal regions, and the demand for the construction of more infrastructure via government investment can be expected to decrease. With increases in the standard of living, development-oriented demands for education, medical care, social security, and public services may increase. All of these changes require the government to reduce direct interference in economic development and provide more public support for sustainable development. Local governments must also cease intervening directly in order to allow market integration across regions.

On the other side is the transition from a relationship-based society to a society based on rules. During the early stages of economic development, social networks play an important role in coordinating trade relationships, especially for a morality- and family-based society like China. Unlike rulebased societies, relationship-based societies do not need large-scale investments to establish rules and are relatively well-suited for the early stages of economic development. However, the disadvantage of this type of society lies in the limitation of the expansion on market transaction scope. It is therefore not well-suited to the demands of modern economic development (Yongqin Wang, 2006a). Rule-based societies, however, require large-scale investments to set up rules and methods of execution and enforcement (including courts and lawyers). However, once these systems have been established, they can be used to coordinate market transactions on a much wider scale, which is beneficial to modern economic development. China has become more and more adept at setting up rule-based systems, and the demand for a rule-based society has become stronger and 
stronger. China must gradually establish a market order based on rules and laws. Public power should be strictly confined to the public domain, and private relationships should be strictly limited to the private area.

The current political and social structures and their interactions with economic development will be illustrated in detail in Chapter 2, and the direction of any adjustments to these systems will be discussed.

\section{Sustainable development in China}

If adjustments to political and social structures can be made in a timely manner, China may achieve sustainable development. This would involve three transitions.

First, the urban and rural populations must be integrated. For the purpose of realizing economic modernization, China should continue to promote rapid urbanization. Currently, the huge rural population has not shared equally in the benefits of the country's industrialization and economic development. Urbanization is not only an issue of increasing the proportion of urban population, but also a challenge of urban and rural integration, which includes at least three components. The preliminary stage of urban-rural integration involves simply transferring rural residents into cities. Social integration is more complicated. If peasants who move into cities are not treated as equals of the original urban residents in terms of public services, job opportunities, and social security, the traditional urban-rural segmentation will transition into a dualistic society within the cities, which will threaten the construction of a harmonious society and the sustainable development of those cities. One alternative to simply moving people into cities is to provide peasants with equal rights to participate in policy making by means of political integration and thus allow them to abolish the economic policies that currently favor cities themselves. The 17th CPC National Congress suggested that the number of National People's Congress (NPC) deputies be selected from urban and rural areas based on population. This would be a critical move toward urban-rural integration.

Second, regional imbalances must be corrected. If the development of the economy continues to widen the gap between regions, interregional income inequality could become rampant. Under a public service system, which is mainly dependent on local budgets, differences in development can lead to differences in social security across regions, which creates barriers to the establishment of a nationwide social security system. This may harm the flow of laborers across regions, so unification of the domestic market should be promoted. This would include integration of the commodity and factor markets. During this process, economic activities would become concentrated in terms of space, which, in the short term, may 
increase gaps across regions. In the long term, however, it would foster regional balance. According to the developmental experiences of other countries, if factors are allowed to flow freely across regions, the income gap between regions will decrease (Shankar and Shah, 2006). In the meantime, in order to ease the conflicts caused by excessively large interregional disparities, it is important to permit fiscal transfers from the central government, especially for a moderate equalization of infrastructure and public services such as education.

Third, China's economic goals must move away from the pursuit of efficiency and toward emphasizing fairness. Under the current fiscally decentralized system, the objects of economic development are mainly focused on the short term, while objects that will benefit long-term economic development are ignored. Under the current market mechanism, growth and efficiency are the first priority, but inequalities in income and public services between urban and rural areas, between regions, and between different groups of people are intensified. Widespread inequality can harm sustainable development in many ways. When the economy has reached a certain stage, it becomes more important to promote sustainable development that will foster moderate equalization of income and public services. Therefore, China must adjust its system of fiscal decentralization; public finance must take up a larger proportion of the government finance spending in order to provide public services relevant to people's lives. Meanwhile, the government should increase investment in moderate equalization of income and public services, especially for moderate equality of public services between urban and rural areas and between regions. For the moment, the flow of population across these areas and regions is partly motivated by differences in the availability and quality of public services. This is not favorable to coordinated development. If all levels of government adopt some means of fostering moderate equalization in public services, less-developed regions will be able to retain more human capital, which will in turn favor sustainable economic development and decrease the cross-regional flow of laborers (for public services only).

Chapters 3-5 will discuss the issues of urban and rural development, regional development, and public services in detail.

\subsection{DRIVING FORCES BEHIND REFORM AND OPENING-UP}

After 30 years of market-oriented reform and opening-up, China is facing a new historical starting point. The questions of what the driving 
force behind deeper reform and further opening-up will be, what kind of universal rule might be used to describe China's journey toward a sustainable system and what lessons other developing countries could derive from China's experience have yet to be answered. In this section, we shall use the concept of a development triangle to illustrate the driving forces behind reform in China.

\section{Development Triangle: Appropriate Institutions, Economic Growth, and Developmental Imbalances}

China's development path comprises a development triangle of three variables: appropriate systems, economic growth, and developmental imbalances (Figure 1.1).

At the beginning of reform and opening-up, the goal driving this developmental triangle was the urgent need for growth and the eradication of poverty. As Deng Xiaoping once said, 'poverty is not socialism'. This statement led to a consensus that countrywide development was necessary, and this consensus was visible across all levels of government. After the political disturbances of 1989 , marketization reform encountered resistance. Deng Xiaoping then suggested that we should judge everything by the fundamental criteria of whether it favors the promotion of productivity, increases the overall strength of the socialist state, and raises people's standard of living. Market-oriented reform and opening-up resumed and developed further.

The rapid growth observed over the past 30 years owes a great deal to these original goals and to China's political and social structure. However, if growth is to continue, then systems appropriate to the current situation must be built. This will promote economic growth, which will in turn correct developmental imbalances.

The decentralized governments and their focus on short-term economic growth have fostered another cause of internal imbalances - income inequality - which has restrained increases in domestic demand. This is why the rapid economic growth has been mainly dependent on investment and exports. Due to the slow increases in domestic demand, local governments have usually increased their own investments in economic growth. This, however, has increased supplies beyond demand.

From the outside, China's macro economy faces a dilemma. Since 2005, China's trade surpluses and foreign reserves have increased significantly. This has not only brought huge pressure to bear on the revaluation of the RMB but has also exacerbated the problem of surplus liquidity. The joint effect of surplus liquidity and social expectations has pushed up asset prices, especially housing prices. 


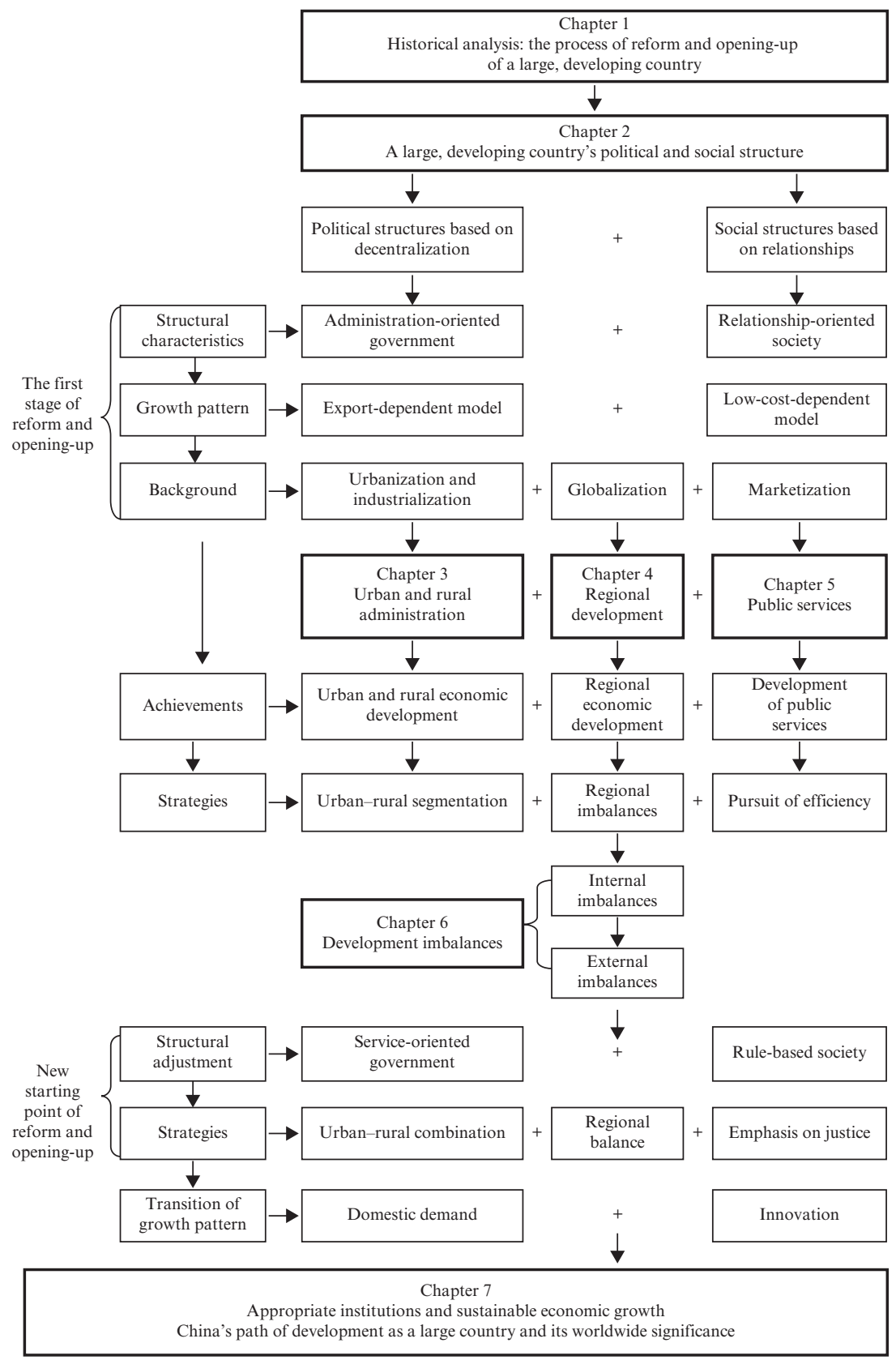

\section{Figure 1.1 China's path toward development}


In fact, foreign reserves have caused a series of macro imbalances. These are related not only to undervaluation of the RMB but also to the low costs of labor, environmental degradation, and low prices of basic materials. Between 1994 and 2004, the wages of migrant workers grew very slowly. After 1996, labor market reform took place in many urban sectors, which dragged down costs even further. During the early stages of opening-up, the low cost of labor was a competitive advantage, and China quickly became the world's manufacturing center. Competition in the labor market increased income inequality, which has had a markedly negative influence on the harmonious development of society and sustainable growth in the economy.

China should address the emerging internal and external imbalances by adjusting its pattern of economic growth and political and social structures. The correction of developmental imbalances will lead to economic growth, and growth will lead to new and more appropriate systems. The second stage of reform and opening-up will take place through interactions between the economy, politics, and society. Thus, China will continually improve upon its socialist market economy with essentially Chinese characteristics.

This chapter has looked back on China's path to reform and opening-up and the specific influence of its status as a large, developing country. In Chapter 2, we investigate the political and social structures underlying its economic development and recommend a transition from an administration- to a service-oriented government and from a relationship- to a rule-based society. In Chapters 3-5, we analyze three important aspects of China's development. Chapter 3 analyzes urban and rural economic development in the context of industrialization and urbanization, and examines types of urban-rural governance that would allow China to promote urban-rural integration. Chapter 4 addresses China's regional economic development in the context of globalization, and maintains that China should realize the transition from regional imbalance to regional balance in terms of regional development. Chapter 5 analyzes the reform of public services in the context of marketization, and recommends a transition from the pursuit of efficiency to the pursuit of a fair distribution of public services. Chapter 6 examines the challenges encountered during the 30 years of unbalanced growth from the perspective of economic development, and notes that in order to foster a harmonious society and sustainable economic growth, China must resolve developmental imbalances by adjusting political and social structures and make the transition from its heavily export-based, cost-dependent economy to one driven by domestic demand and innovation. Finally, Chapter 7 examines China's development and its worldwide significance. 


\section{China's Path toward Development and the Significance of that Path}

China's political and social systems have many quintessentially Chinese characteristics. These have been adapted to its needs as a large, developing country. The progression from the active adjustment of policies under established political and social structures to the self-adjustment of those structures is key to the continuous improvement this or any socialist market economy with Chinese characteristics.

When viewed over time, China's path toward modernization can be said to have involved interactions between politics, economy, and social factors. To continue down this path, China must build and support appropriate institutions, as recently proposed by economists (Djankov et al., 2002; Acemoglu et al., 2006). Chinese scholars, however, have long recognized the importance of the adaptation of existing institutions to national conditions. In his investigation of the history of Chinese political systems, Qian Mu said, 'political systems should develop on their own. Some political systems can be introduced from other countries, but these may not be effective until they are merged into the nation's traditions. Politics cannot exist without life and institutions cannot survive without support' (Qian, 1952 [2001], preface).

China's development has involved unique political and social structures. Under specific historical and cultural conditions, different countries may adopt different developmental paths and still realize very similar goals, in this case, modernization. In terms of traditional viewpoints, some forms of modernization are required. These include democracy, liberty, and private property. However, modern economics has shown that adjustments in political and social structures do not begin until the economy has developed to a certain point. During the early stages of economic development, China adopted market-oriented policies of reform and opening-up, creating an economic boom under established political and social structures. However, China must adjust those of its political and social structures that are relevant to the market economy system if sustainable economic development is to continue. This might explain why modernization can take so many paths.

Academically, studies of China's development focusing on its status as a large country are in accordance with the trends of modern economics. Modern economics no longer considers development as the processes of industrialization and urbanization; economists have recognized that economic development is followed by a series of adjustments in political and social structures. Some scholars are trying to develop a macro-historical theory that can explain the interactive processes of underlying political, social, and economic development in Western countries. They believe that 
in Western Europe, the early stages of development were 'limited access orders', in which elites exercised privileges in politics, social organizations, and education, and these privileges created a self-sustaining system in which elites actively excluded others. During these early stages, economic development served the interests of the elites. However, as development continued, limited access orders restricted competition and the scope of the market and decreased incentives for economic development. Before further economic development could take place, Western Europe had to enter a stage of open-access social orders, where all political, educational, and social organizations were opened up to the people, and the privileges of elite individuals and organizations were restrained (North et al., 2006).

Strictly speaking, China has never implemented the Western European model of limited-access orders. For the most part, politics and education in China have been open to most people (Qian, 1952 [2001]). Because of these differences, we need to apply different logical models in order to explain China's development.

China's development indicates that established political and social structures might change if the current system cannot maintain the required high degree of social mobility and low degree of income inequality. In other words, the rigidity of the political and social structures may motivate reform. The limited- and open-access orders put forward by North et al. (2006) consider development to be a one-off process of adjustment. The motivation for development is not lost once a society institutes openaccess orders. In the development triangle comprising appropriate institutions, economic growth, and developmental imbalances, the interactions among the economy, politics, and society take place continuously. In the sense of the comparative system, if Chinese characteristics do affect the country's modernization, then the differences between the socialist market economy system with Chinese characteristics and other market economy systems will create a new topic of interest for economists.

We have tried to set up a development theory from the perspective of the political and social structures of economic development based on China's history. If the growth strategy concentrates on changes in GDP (size of economy), then we may understand the development process as an interactive process incorporating the economy, politics, and society. The core of modern economics involves drawing boundaries between markets and government. However, adjusting these relationships to promote economic development remains challenging. In traditional economics, knowledge of institutional changes and structural adjustments is limited. In a given situation, there are many static theories that can be used to explain the relationship between the market and government. However, there is no existing economic theory that can explain how the relationship between 
market and government changes over time and across space. Viewing the development process as an interaction between the economy, politics, and society can enrich comprehension of institutional changes in economics, and then modern economics can be used to analyze the dynamic process of development.

\section{NOTES}

1. See UNDP, Human Development Report 2006, available at: http://www.undp.org.

2. See China Statistical Summary 2006, China Statistics Press; China Statistical Summary 2007, China Statistics Press; http://Zhs.Mofcom.Gov.Cn/; Almanac of China's Finance and Banking 1993, Almanac of China's Finance and Banking Magazine Co. Ltd; China Monthly Statistics, December 2006, China Statistics Advice Center. Data in 2009 are from China Statistical Yearbook 2010, China Statistics Press.

3. See Report of Foreign Investment in China 2006, Ministry of Commerce of the People's Republic of China; Almanac of Economy and Trade 2006, People's Press.

4. See Statistical Communiqué on the 1979 National Economic and Social Development of the People's Republic of China; Results Communiqué on the 1981 National Economic Plans of the People's Republic of China; Statistical Communiqué on the 1992 National Economic and Social Development of the People's Republic of China; available at: http://www.stats.gov.cn/.

5. See China Statistical Summary 2007, China Statistics Press. Secondary industry includes industry and construction, tertiary industry includes transportation, storage, postal services and wholesale and retail trade.

6. In his 'On the ten major relationships' in 1956, Mao Zedong described the relationship among heavy industry, light industry, and agriculture, the relationship between industry in the coastal regions and industry in the interior, and the relationship between the central and local authorities. Looking at the challenges and problems China faces today, it is clear that some problems have persisted for a long time and they may continue beyond the transition from a planned to a market economy. 